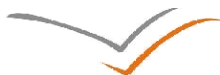 \\ VERSITA
}

\section{Successfulness of Slovenian Economomic Transition?}

Lea Prijon

School of Advanced Social Studies, Nova Gorica, Slovenia

\begin{abstract}
Successfulness of Slovenian Economic Transition? At the beginning of nineties, countries from so-called communist block had experienced transformation process from socialist regime to a democratic one, and transformation from centrally planned economy into a free market economy. Many countries had gone through process of transition, but it had different results and effects on individual countries and societies. The success of transition is strongly linked with country's history and cultural bases; it depends on country's openness to specific reforms and on the approach of transition (shock therapy or gradualism). Slovenia was initially seen as a country with the best starting position at the beginning of transition, compared to other countries that went through the same process. However, today Slovenia is facing problems regarding economic system, political system, civil society etc. Today's situation in Slovenia seems to be much worse than it is in some other transition countries with worse starting position. The purpose of the article will be to examine Slovenian transition compared to other countries and detaching factors that disabled its full development.
\end{abstract}

Key words: transition, shock therapy, gradualism, economic system.

Úspešnost' slovinskej ekonomickej tranzície? Začiatkom 90. rokov krajiny bývalého sovietskeho bloku prechádzali transformačným procesom zo socialistických režimov na demokratické, rovnako aj z centrálne plánovaného hospodárstva na trhové. Množstvo krajín sa $v$ tomto ohl'ade transformovalo s rôznymi dôsledkami na politiku a spoločnost'. Úspech prechodu k demokracii je úzko spätý s historickým a kultúrnym vývojom a záleží na ochote štátu prijímat' špecifické reformy a prístupy transformácie (šoková terapia alebo postupná reforma). Slovinsko bolo, v porovnaní s inými štátmi, považované za krajinu s najlepšou východiskovou situáciou na začiatku prechodu. Napriek tomu však súčasná situácia v Slovinsku zaznamenáva väčšie problem ako krajiny, ktoré mali horšie podmienky. Ciel'om štúdie je analyzovat' prechod $k$ demokracii $v$ Slovinsku a porovnat' ho s ostatnými krajinami strednej a východnej Európy a reflektovat' dôvody, prečo je táto tranzícia konfliktná vo viacerých aspektoch spoločensko - politického života.

Klúčové slová: prechod k demokracii, šoková terapia, postupná reforma, hospodársky systém

\section{Introduction}

Success of transition is a topic that raises interest in a number of debates among economists, political scientists and sociologists. After more than two decades since the beginning, analysis of the situation in transition countries is possible. Process of transition dependent on the initial position of the particular state, its historical, cultural, political and economic basis. Analysis of current political

210 Slovak Journal of Political Sciences, Volume 12, 2012, No. 3 DOI: $10.2478 /$ sjps-2013-0005 
and economic situation of these countries is even more interesting and complex since transition occurred in two models. Some countries have adopted shock (also big bang) theory, while others decided for gradualist process. We will analyse the performance of Slovenian economic transition, comparing it with some of other transition countries: Slovakia, Poland, Hungary and Czech Republic. Such a selection of countries lies mainly in the fact that all are located in Central and Eastern Europe, they have experienced the similar political system, most of them are arising from the same group of languages (except Hungary), all started the transition in the same time, and all simultaneously joined the European Union. While analysing Slovenian transition we will try to determinate its successfulness compared with other aforementioned countries. The object of analyses is particularly interesting since the Czech Republic, Poland and Slovakia opted for shock therapy, while Slovakia and Hungary decided for more gradual transformation. The issue is, if adoption of one model or another, could determine the successfulness of transition and thus influence the actual economic situation of these countries.

Highlighting the problem in the very beginning in the title of the paper itself, Successfulness of Slovenian transition, implies the definition of the term "successfulness". What is successfulness of the transition and how can we define it? Stiglitz (1999) claims that development of market economy itself, does not necessary mean successfulness of transition. According to him the objective of transition is improvement of life standard and consolidation of democratic system. As main macroeconomic indicators of successful transition Senjur (2001) lists; level of real GDP growth, GDP per capita, inflation rate, unemployment rate, budgetary balance and current account balance. In addition to these indicators Roland (2001) adds also payment inequality and life expectancy. According to Haček (2001) one important indicators of (un)successfulness is also external debt. Next to aforementioned indicators, the share of foreign direct investments can also be understood as one of the aspects (un)successfulness.

In defining the successfulness of listed transition countries we will examine three indicators; the level of gross domestic product (GDP), gross domestic product per capita (GDP p.c.) and share of foreign direct investments (FDI) will be as. For the case of Slovenia we will shortly examine the share of trade (import and export) as criteria for defining Slovenian economic successfulness after the transition.

\section{Theoretical conceptualisation of transition}

Transition process, which started in 1989/90 generally refers to the collapse of Communism (with the fall of the Berlin Wall in 1989) and applies to East and Central Europe. It covers all institutional changes; transformation of political 
system (from communism and socialism to democracy) and economic system (from centrally planned to market oriented economy), it also concerns establishment of democratic institutions, division of powers, freedom of speech, entrepreneurship initiatives etc. (Pezdir, 2008: 20-22, 88). In politics and economics transition process demands a set of socio-political norms, institutions and regulations, located between the state and market, what (Linz and Stepan, 1996: 21) call economic society. The latter is particularly important in terms of democracy, which cannot be fully consolidated in the central planning economy, nor in already established market economy. Since in strong democracies there is a market intervention and state ownership (see Przeworski et al., 1996). Regardless, the development of market economy (and economic prosperity) and consolidation of democracy are interconnected, interdependent and indispensable. One of transitional aims is also transformation of the collectivist society in individualistic one, based on freedom of choice, which is one of the essential feature of capitalism (Pezdir, ibid.).

At the beginning of transition, the actual economic situation has not been completely defined. Plans for new economic system and adequate solutions to problems have not been outlined by the shareholders in transition. Assumptions of the later were just assumptions taken for granted, that transition will start and led to the elimination of deformed (non)market institutions, to restructured market and private property, introducing a laissez-faire market mechanism and transforming the socialist (centrally planned) economy into the welfare state. International financial institutions, foreign consultants and foreign policy experts, advised countries that began the transition. Menciger claims: "their basic goal was the final abolition of socialism and the existing institutions, rather than the gradual creation of proper economic system for each country and the increase of economic prosperity for all society, not just a part of it" (Mencinger, 2000: 28). And emphasizes Soros's definition of market economy: "Previous ideology ,the prevention of capitalist exploitation “ was replaced by new ideology of "market fundamentalism", as a faith in the unlimited potential of the market economy" (Soros in Mencinger, 2000: 28).

Transition process can occur in two ways: with gradualism or shock therapy. The first approach is incremental and proceeds on basis of cooperation with the society in order to transform political and economic structure. Therefore, a more intensive involvement of the public and active participation of state institutions is needed and characteristic for gradualist approach. Murrell (1993) emphasizes the importance of history and society for economic system and their need of involvement during transition process. Gradualist approach is keen of a longer lasting state intervention in economy (what can be found in fixed exchange rates, delayed privatization, wage controls etc. (see Hall and Elliott, 1999). 
Shock therapy (also known as Big-bang) approach implies an immediate impact on the state (political system), society and economic system. Thus, it implies radical and rapid changes on all spheres of the society, producing a negative economic shock. The driving idea behind Shock Therapy is to implement liberal government structures and economic policies and to create a fully functional market within a short amount of time. The idea of shock therapy is supported by neo-liberal authors (Buchanan, Friedman, Hayek etc.), who argue, that the absence of the state, market driven allocation of resources will create economic growth. This could be reach with deregulation of prices and the exchange rate, free trade, privatisation and macroeconomic stabilisation (see Hall and Elliott, 1999; Lipton and Sachs, 1990).

Defining which transition approach has been adopted by each country is rather difficult, since single measures are defined differently in each country. For example the liberalization of prices is in Poland seen as a shock therapy, in Hungary on the other hand, is defined as one of gradualist measures. In Slovenia, the liberalization of prices is defined as an initial condition of transition (Mencinger, 2000: 28).

Gomulka gives three new divisions of transition approaches ${ }^{1}$ (hereinafter see Gomulka, 2000):

1. Shock therapy model, typical for transition in former Eastern Germany,

2. Gradualist model, typical for former countries of the Soviet Union,

3. Model of fast adaptation, typical for all Eastern European economies.

Restructuring the economic system form centrally planned to market economy, concerns three main reforms (hereinafter Menciger, 2000: 29-31):

1. Privatisation, concerning orderly and lawful transfer of ownership rights of "the public" - the government and other public institutions to subject of civil law - individuals and societies. Private property is a key component for market economy, is believed to improve economic efficiency, ensure fairness in the distribution of wealth and prosperity, eliminate one-party system, optimize the utilization of capacity and risk etc.

2. Macroeconomic stabilization, which should led form "monetary overhang" (typical for socialistic economies) to "Washington Accord"2, meaning the actual macroeconomic stabilization.

\footnotetext{
${ }^{1}$ Menciger finds Gomulka's models as unsuitable. The same is for Gomulka's claims, model of fast adaptation providing relative success in transition countries of Eastern European and gradualism causing the fail in countries from former Soviet Union (Mencinger, 2000: 28).

${ }^{2}$ Washington agreement is an agreement between the World Bank, International Monetary fund and the U.S. government. It is based on the hypothesis that aggregate demand exceeds aggregate supply. The measure implied a reduction of excess demand by increasing supply through liberalization of trade and the reduction of demand by restrictive monetary and fiscal policy,
} 
3. Restructuring, defined by Landesman (see 2000) as a change in the composition of the product, employment rate, trade and a change in the relationship of economic aggregates, reflected by production or employment function. Restructuring is strongly linked with privatization and macroeconomic stabilization, which influenced the structure of the economy and changing the links between economic aggregates.

Menciger argues that much of the rapid structural changes were forced rather than necessary for development level, creating unnecessary or even harmful institutions in less developed socialist economies, not contributing in changing their economic system. Restructuring has often acted as an experiment with unnecessary financial institutions on the one hand, and destinies of thousands of employees on the other (Menciger, ibid).

After almost two decades many authors are questioning which of these two approaches have been more successful. Havrylyshyn claims: "Countries that adopted far reaching reforms tended to experience higher growth rates and lower inflation and received more foreign investment. Inequality increased less among rapid reformers than among gradual reformers. The same is true with respect to poverty rates" (Havrylyshyn, 2007: 1). However, such simple conclusions could not be made, without first analysing country's historical and cultural background. Examining today's situation of some transitional countries, which implemented Shock therapy as a way of transforming the society, like Estonia, Czech Republic, Slovakia are more successful compared to countries which had chosen the gradualist approach (Russia, Ukraine, Belarus, Slovenia etc.).

\section{Comparison of transition in selected countries}

Countries involved in transition have had different economic and political system, different levels of civilization competence, degree of economic, social and cultural capital, etc.. All these components are, in the opinion of many authors, the key factor of process and successfulness of transition. In this part we will examine the process of transition in five selected countries (Slovenia, Czech Republic, Slovakia, Poland and Hungary). Starting with data of their GDP and GDP p.c. in 1990, 1995, 2000, 2005 and 2005, the purpose is examining their initial position and further analysing the transition progress trend. The reason for such an analysis and comparison is to compare Slovenia, which is considered as the country with the best starting position among other transition countries (Adam, 1989: 28-29).

price liberalization, fixed exchange rate, and the freezing of wages and government expenditure (Menciger, 2000: 29-31). 
Table 1: Starting position of transition countries by GDP* and GDP p.c.** by year (in \$)

\begin{tabular}{|c|c|c|c|c|c|c|}
\hline & & $\begin{array}{c}\text { SLOVENIA } \\
\left(20,2 \mathrm{~km}^{2} / 2\right. \\
\text { mil })^{* * *}\end{array}$ & $\begin{array}{c}\text { CZECH } \\
\text { REPUBLIC } \\
\left(78,866 \mathrm{~km}^{2} / 10,5\right. \\
\text { mil })^{* * *}\end{array}$ & $\begin{array}{c}\text { HUNGARY } \\
\left(93 \mathrm{~km}^{2} / 10\right. \\
\text { mil })^{* * *}\end{array}$ & $\begin{array}{c}\text { POLAND } \\
\left(312,6 \mathrm{~km}^{2} / 38,5\right. \\
\text { mil })^{* * *}\end{array}$ & $\begin{array}{c}\text { SLOVAKIA } \\
\left(49 \mathrm{~km}^{2} / 5,5\right. \\
\text { mil })^{* * *}\end{array}$ \\
\hline \multirow[b]{2}{*}{1990} & GDP & $17,381,802,758$ & $34,879,966,071$ & $33,056,134,799$ & $64,549,596,206$ & $11,716,492,830$ \\
\hline & $\begin{array}{c}\text { GDP } \\
\text { p.c. }\end{array}$ & 8,699 & 3,375 & 3,186 & 1,694 & 2,211 \\
\hline \multirow[b]{2}{*}{1995} & GDP & $20,940,864,809$ & $55,257,045,968$ & $45,561,413,231$ & $139,061,765,458$ & $25,253,597,386$ \\
\hline & $\begin{array}{c}\text { GDP } \\
\text { p.c. }\end{array}$ & 10,524 & 5,351 & 4,411 & 3,603 & 4,710 \\
\hline \multirow[b]{2}{*}{2000} & GDP & $19,979,467,790$ & $56,720,835,331$ & $46,385,589,534$ & $171,276,118,424$ & $28,724,041,828$ \\
\hline & $\begin{array}{c}\text { GDP } \\
\text { p.c. }\end{array}$ & 10,045 & 5,522 & 4,543 & 4,454 & 5,330 \\
\hline \multirow[b]{2}{*}{2005} & GDP & $35,717,733,757$ & $124,548,570,554$ & $110,321,711,573$ & $303,912,247,951$ & $61,328,471,583$ \\
\hline & $\begin{array}{c}\text { GDP } \\
\text { p.c. }\end{array}$ & 17,855 & 12,168 & 10,937 & 7,963 & 11,385 \\
\hline \multirow[b]{2}{*}{2010} & GDP & $46,908,328,072$ & $192,032,097,602$ & $128,631,634,125$ & $469,440,132,670$ & $87,268,098,543$ \\
\hline & $\begin{array}{c}\text { GDP } \\
\text { p.c. }\end{array}$ & 22,893 & 18,254 & 12,863 & 12,294 & 16,071 \\
\hline
\end{tabular}

* GROSS DOMESTIC PRODUCT (national)

** GROSS DOMESTIC PRODUCT (per capita)

*** Numbers of country's area and population are rounded to one decimal

Source: The World Bank, 2012

After the transition "three-pole political geography" emerged in the territory of former communist Europe, divided into: the new Central Europe (represented by the Visegrad countries, Baltic countries and Slovenia), the Balkans and the area from east of Poland (with Russia and other former Soviet countries). These countries have had different developmental opportunities and it were precisely the Central European countries (including Slovenia) that have had better opportunities (Rupnik et al., 2001: 21). Regardless, this was not quite true for Slovenia. Table 1 shows the real GDP and GDP per capita. Real GDP of individual country shows that in 1990 only Slovakia (which is more than twice as big as Slovenia) had the lower real GDP compared to Slovenia. Czech Republic, Poland and Hungary had significantly higher real GDP compared with Slovenia, due to their size and population. The interesting trend can be observed in reducing the gap between Slovenian real GDP from 1990 to 
2010 compared to other countries. Slovenian real GDP grew for 2,7 times from 1990 to 2010, (the Czech Republic GDP grew for 5,5 times, Hungarian for 3,9 times, Polish for 7,2 times and Slovakian for 7,5 times). This clearly shows that all other transition countries were developing much faster than Slovenia, which started from better position. Slovenia was in pole position compared to other countries also considering GDP p.c., starting from 8.699 \$, which is 5 times more compared to Poland, with the lowest GDP p.c. in the same year. But today's difference between the two countries is only for 1,8 times. Similar differences are also evident in comparison to other countries.

If we compare Slovenia and Hungary, data show that the Slovenian GDP p.c. was for 2,7 times higher in the beginning of transition (1990), compared to Hungarian. But in 2010 Slovenian GDP was higher only for 1,7 times. Slovenian GDP p.c. increased from 1990 to 2010 for 2.6 times, while Hungarian for more than 4 times. Also referring to Hungarian real GDP, which was for 1.9 times higher compared to Slovenian in 1990, but in 2010 Hungarian real GDP is more than 4 times bigger. As already mentioned earlier, today's Slovenian real GDP is 2.7 times higher than in 1990, but Hungarian for 3.9 times higher. From this data it is evident that also Hungary, which adopted the same approach for transition was developing a lot faster than Slovenia did.

Zver (et al., 2005: 75-76) believe that in the transition countries pre-modern cultural trends still exist, which may act as a contra culture, and may represent a negation of modernist or post-modernist culture. They can be seen in rejection of democracy, in adopting autocracy, expertocracy, the system of privileges, state control, legitimizing tax evasion, corruption, etc. But, considering data above, it is evident that all these countries were developing a lot faster than Slovenia did. Which arises questions, how such a lack is possible and how could all these countries develop faster. The issue is even more critical considering the best starting position Slovenia had at the beginning of transition, and considering its political system, which was more lenient compared to all these countries.

Nevertheless, according to Paldam and Svendsen (2000: 1) economic development of countries involved in transition has been disappointing in three ways:

1. The output collapse just after the big change in 1989/90 was on average $40 \%$ of GDP.

2. The upward trend has been slow, in some cases it has hardly even started.

3. Increased corruption, rent-seeking and crime.

At this stage it is essential to highlight that development of an economy is strongly linked with essential economic laws (needed for transition to market oriented economy), which are not always in harmony with government policy 
and country's transitional strategy. In some transition countries privatisation, macroeconomic stabilization and restructuring of economic system is still not completely finished. Some countries managed to execute the process of privatization (e.g. Hungary and Czech Republic), while others were/are more cautious or even ineffective (Bulgaria, Russia, Serbia). Many countries, especially the newly independent and autonomous one, like Slovenia, Croatia, Estonia, Lithuania, Latvia, Slovakia, and Macedonia, faced other problems linked with restructuring of their economic system. For all newly created countries, economic openness and external cooperation is crucial. All listed countries were of an import substitutive nature linked with the Yugoslav market and the Eastern European market, until 1990. The biggest problem they faced is the loss of their market, without the possibility of gradual transition and adaptation (Lorber, 1999: 144).

\section{Foreign direct investments in transition countries}

Foreign Direct Investments (FDI) is a key component of a developed economy and necessary for economic growth and stability. For countries in transition encouraging FDI was even more important, since they contribute to the reduction of developmental delay, compared to other developed countries. Interests for foreign direct investments differ within countries. Some transition countries have successfully created attractive conditions for foreign investors and have, as such, increased interests for developed countries to invest in them. This has facilitated transition countries to invest in the revitalization of own industry and to modernize their technological production. Foreign investors are interested in countries with appropriate legislation to provide protection for private capital, regulate the tax policy, and ensure optimal conditions for the development of the market economy (Lorber, 1999: 142-143).

According to Dunning (1993) there are three main reasons for foreign direct investments, which are associated with specific business benefits of companies; site-specific advantages and internalization advantages. The latter benefit is crucial and depends of each country. Specific locational advantages implicate production costs, marketing factors and different types of government policies. Dunning, as crucial motives for investment, considers; cheap resources, seeking for new markets, increasing efficiency by diversifying risks, and strategic goals. In analysing factors that influence foreign investor to invest in a specific country, Foley (1996) found that this effect depends on the individual investor, its strategies and motivation for the investment, the size of the business and investment, types of investments etc. In his study he found that the most important factor motivating a foreign investor is access to new markets. 
In the table below (Table 2) data of foreign direct investments (FDI) in transition countries are given. Data will show the attractiveness of a specific transition country for foreign investors. Due to the lack of some data form 1990, only FDIs from 1995 to 2010 are considered.

Table 2: Foreign direct investments (FDI) in countries in transition (in \$)

\begin{tabular}{|l|l|l|l|l|l|}
\hline & \multicolumn{1}{|c|}{$\mathbf{1 9 9 0}$} & \multicolumn{1}{c|}{$\mathbf{1 9 9 5}$} & \multicolumn{1}{c|}{$\mathbf{2 0 0 0}$} & \multicolumn{1}{c|}{$\mathbf{2 0 0 5}$} & \multicolumn{1}{c|}{$\mathbf{2 0 1 0}$} \\
\hline $\begin{array}{l}\text { Czech } \\
\text { Republic }\end{array}$ & n.d. * & $2,567,564,642$ & $4,987,079,129$ & $11,601,978,991$ & $6,720,074,107$ \\
\hline Hungary & $553,808,992$ & $4,804,151,332$ & $2,770,479,254$ & $7,626,151,047$ & $-42,283,449,518$ \\
\hline Poland & $89,000,000$ & $3,659,000,000$ & $9,343,000,000$ & $10,309,000,000$ & $9,104,000,000$ \\
\hline Slovakia & n.d. * & $236,132,979$ & $2,052,480,853$ & $2,411,132,115$ & $553,142,912$ \\
\hline Slovenia & n.d. * & $150,400,000$ & $135,800,000$ & $540,400,000$ & $366,161,963$ \\
\hline
\end{tabular}

* n. d. = No data

Source: The World Bank, 2012

Data show that Slovenia had the less FDI in the period between 1990 to 2005 compared to other transition countries, only Hungary had negative FDIs in 2010. Nevertheless, the trend of FDI was from 1995 till 2010 much higher compared to Slovenian FDIs. Adaptation to market oriented conditions and adoption of appropriate legislation was uneven in transition countries. Hungary was the first country to adopt the appropriate legislation, therefore in the beginning period the proportion of direct investments was the largest. The following country for FDI's interests were Poland and Czech Republic, which had broken with its previous regime quite radically and had a strongly developed industry with a skilled work force. Lorber (1999: 142-143) explains this with the basis of their orderly legislation and political stability.

Considering only Slovenian FDIs they are still low, the highest proportions of FDI's inflow are from Austria, outward FDI are in Croatia ${ }^{3}$. From 1993 interests for outward FDIs was also in Poland, Russia, Czech Republic and Bosnia and Herzegovina. In the same period (from 1993 - 1997) the share of Slovenian FDI in Germany, Austria and Macedonia was strongly reduced. After 1997 investments in Austria started to grow again, the same trend was in Liberia and USA, outward FDIs in Yugoslavia was reduced at this period. Svetličič et al. are questioning the future of Slovenian FDIs, since its trend is decreasing in the period when creating and investing in enterprises abroad, is becoming the most important strategy of penetrating the foreign markets. Slovenian enterprises are moving their investment shares in these enterprises

${ }^{3}$ At the end of 1997 the share of total outward FDIs amounted of 53,7\% in Croatia (Svetličič et al., 2000: 629). 
(e.g. Germany, Austria, Macedonia) or their presence is kept in a relatively modest level, focusing mainly in Croatia (Svetličič et al., 2000: 629-630). The share of FDI is relatively low also compared to some other transition and new EU member-states countries (e.g. Poland or the Baltic states). The reason for such a situation can be found in Slovenian reluctance to foreign investors which are viewed with mistrust by Slovenian policy-makers and general overall opinion. Slovenian government also adopter certain measures, which were an obstacle for foreign investors and resulted as a prevention for investing in Slovenia (Rojec and Kovač, 1999: 7).

\section{Conclusion: Slovenian transition and its successfulness?}

Many Slovenian authors are questioning the successfulness of transition and much of the literature argue this transformation not being quite successful or as accomplishing as it could be. At the end of 1990, the World Bank and the Yugoslav Government had jointly planed the transformation of Yugoslav economy, where measures would result in the restructuring of banks and companies. World Bank intended to grant a loan to Yugoslavia from a new class of loans dedicated to adjustment for the financial sector. In such a system, foreign economies had seen a guarantee of abandonment of socialism and the opportunity for the transformation of the Yugoslav economy into a modern market economy (Borak, 1997: 536-537).

Slovenian ${ }^{4}$ transition started with implementation of new Slovenian constitution, but conflicts between defenders of big-bangers and gradualists emerged. Most of disagreements emerged in the debate of privatization, which could have taken place in two ways: gradual decentralized and amortized privatization or quick centralized and distributive. The result of these conflicts has been delayed adoption of Ownership Transformation Law (adopted in November 1992), adopted as a compromise between the two ways of privatization (Mencinger, 2000: 31-32).

Slovenian gradualist measures of transition are evident in the slow privatization, in maintaining the state's role in economy and in the low share of foreign investment, in the allocation of resources through the political market etc. These generated a low level of economic freedom, were political and economic market were highly related. Despite its significantly better starting position, compared to other transition countries, today's Slovenian economic situation is very poor (Pezdir, 2008: 78-82). If some authors (e.g. Pezdir, Adam, Šušteršič etc.) believe that it was gradualism that had "lead" Slovenia to decline (or at least to slow progress), Menciger (2000: 32) believes that

\footnotetext{
${ }^{4}$ In that time Socialist Republic of Slovenia (one of six countries within Socialist Federal Republic of Yugoslavia).
} 
precisely the very gradual (except for partial privatization) approach, have proven to be successful in preparing macroeconomic frameworks for the "new" Slovenian economy before independence. In 1999, Slovenia achieved relatively good economic results, due to deterioration of the national-economic balance and due to gradual structural reforms (see Kovač, 2000).

Menciger argues that favourable conditions were created by the initial halfcompleted economic reforms in Yugoslavia and basis of then dominant economic system, social ownership and self-management, characterized by the autonomy of enterprises, socially stable population, a sufficiently diversified and modern industry, partly present private service sector etc. On the other hand, Tomšič (2002) argues gradualism maintaining monopoles and restriction of foreign competition, which was linked to maintaining the important role of a country in the economy. Prices were still regulated and the policy of adjustment the exchange rate through manipulation (attempt to promote exports through constant minimal depreciation) has been introduced. State enterprises were being subsidized and were far from the market mechanism. Institutions of economic policy regulations have opted for an active policy by setting up a reconstruction fund for the transformation of enterprises. Monopoles were created and maintained under the pretext of uniting the companies (especially public) for providing them protection against competition. Foreign capital has always been "hated", privatization has encouraged the emergence of affiliated economy and foreign investments have been administratively constrained until 2000. Afterwards they were limited by political sentiment, since domestic companies were not sell to foreigners, due to national interest (Pezdir, 2008: 98). Even after the transition, Slovenian economic system is still quite regulated, there is weak development of entrepreneurship, low economic innovation, restricting foreign competition, modest efficiency of investment in research and development and education, lack of flexible labour market etc. (see Tomšič and Prijon, 2012).

Negative impact of gradualism can be detached also in economic openness and cooperation of Slovenian economy, which is essential for every country, whether developed or not. But foreign cooperation is especially crucial for developing countries thus, for transition countries. The highest share of Slovenian economic cooperation is with European Union, especially with Italy, Germany, France, and Austria (Embassy of the Republic of Slovenia Ottawa). Slovenia imports the greater share of goods from named countries (Izvozno okno, 2011), while the highest percentage of total trading (including import and export) takes place with Germany and Italy. At the beginning of the millennium Slovenian external openness increased significantly till 2007 (in 2010 the trend was lower), deceasing mainly due to the strong reduction of change in GDP in Slovenia in the initial period of crisis. In 2008 the general 
decline in global trade affected the majority of small open economies, but in general less than in Slovenia. The average increase in the external openness of small countries in 2010 was lower for 3.2\% as it was Slovenia (5.7\%) (IMAD, 2011: 103/215).

Slovenian export amounted to 18.2 billion euro in 2010 and enabled economic growth and gross domestic product (GDP) for 1.2\% (Slovenian Chamber of Commerce and Industry: A program to strengthen the internationalization of the Slovenian economy "Go International", 2011). Due to the global economic crisis the general level of trading decreased in 2008, increasing slightly due to recovery of foreign demand in 2010. This generated higher level of international trade integration (the average share of trade in goods and services in GDP amounted of $63.1 \%$ ), which was still lower than in the period between 2006 and 2008. The share of imports was higher, compared to export and generally speaking Slovenian merchandise export growth was slower compared to most other EU countries. International trade share in services (in GDP) has remained at the same level as the previous year (IMAD, 2011: 103/215). Difficulties of TML DirectSlovenian economy is visible in its small, two million market, in fact almost $70 \%$ of revenue are achieved in national market ${ }^{5}$, which points to its economic closeness.

\section{REFERENCES}

Adam, F., 1989. Deformirana modernizacija: (Realni)socializem med tradicijo in modernostjo. In: Družboslovne razprave vol. 6, no. 7, pp. 19-30.

Adam, F.; Makarovič, M., Rončevič, B. and Tomšič, M., 2001: Sociokulturni dejavniki razvojne uspešnosti. Ljubljana: Fakulteta za družbene vede.

Borak, N., 2002. Ekonomski vidiki delovanja in razpada Jugoslavije. Ljubljana: Znanstveno in publicistično središče.

Dunning, J. H., 1993. Multinational Enterprises and the Global Economy. Reading: Adison - Wesley Publishing Company.

Foley, M., 1996. Investment Incentives and Subsidies. Sixth Plenary Meeting. Bled: OECD Advisory Group on Investment.

Gomulka, S., 2000. Macroeconomic Policies and Achievements in Transition Economies, 1989 - 1999. Geneva: UNECE.

Haček, M., 2001. Proces ekonomske konsolidacije v državah nekdanje Jugoslavije. In: Fink-Hafner, D. and Haček, M. (eds.): Demokratični prehodi II. Ljubljana: Fakulteta za družbene vede. pp. 237-251.

Havrylyshyn, O., 2007. Economic recovery in the Commonwealth of Independent States. Toronto: Munk Centre for International Studies.

\footnotetext{
${ }^{5}$ In Slovenia there are about 100 of the most important exporters creating $50 \%$ of total exports and 800 companies that realize more than $85 \%$ of total Slovenian exports (Slovenian Chamber of Commerce: A program to strengthen the internationalization of the Slovenian economy "Go International", 2011).
} 
Hall, T. W., and Elliott, J. E., 1999. Poland and Russia One Decade after Shock Therapy. In: Journal of Economic Issues, vol. 33, no. 2, pp. 305-314.

Linz, J. and Stepan A., 1996. Towards Consolidated Democracy. In: Journal of Democracy, vol. 5, pp. 14-33.

Kovač, B., 2000. Kakovost slovenskih menedžerjev kot intelektualni kapital slovenskega gospodarstva. In: Zbornik računovodij in finančnih revizorjev Slovenije. Ljubljana.

Institute of Macroeconomic analysis and development - IMAD, 2011. Delež izvoza in uvoza v BDP, Poročilo o razvoju, 103/215 - 104/215.

Landesmann, M.A. and Pichelmann, K., 2000. Unemployment in Europe. London: McMillan Press.

Lipton, D., and Sachs, J., 1990. Creating a Market Economy in Eastern Europe: The Case of Poland. In Brookings Papers on Economic Activity, no. 1, pp. 75-147.

Lorber, L., 1999. The economic transition of Slovenia in the process of globalization. In: Geografski zbornik, no. 39.

Mencinger, J., 2000. Deset let pozneje: tranzicija - uspeh, polom ali nekaj vmes. In: Gospodarska gibanja, no. 317, pp. 25-42

Murrell, P., 1993. What is Shock Therapy? What Did it Do in Poland and Russia? In: Post-Soviet Affairs, vol. 9, no. 2, pp. 111-140.

Paldam, M. and Svendsen, G. T., 2000. Missing social capital and the transition in Eastern Europe. Conference paper, IMAD conference. Portorož.

Pezdir, R., 2008. Slovenska tranzicija od Kardelja do Tajkunov. Ljubljana: Časnik Finance.

Przeworski, A.; Michael, A. Cheibub, J. A. and Limongi F., 1996. What Makes Democracies Endure? In: Journal of Democracy, no. 5, pp. 39-55.

Rojec, M. and Kovač, M., 1999. Spodbujanje neposrednih tujih investicij (NTI) v Slovenijo v pogojih članstva v Evrospki uniji. In IB revija, no. 4, pp. 64-74.

Roland G., 2001. Ten years fter... Transition and economics. In: IMF Staff Papers, no. 48. Special Issue.

Senjur, M., 2001. Makroekonomija majhnega odprtega gospodarstva. Maribor: Založba MER.

Slovenian Chamber of Commerce and Industry - CCIS, 2011. Program za krepitev internacionalizacije slovenskega gospodarstva "Go International Slovenia".

Stiglitz, J., 1999. Whither Reform. Annual Bank Conference in Development Economic. Washington: WB.

Svetličič, M.; Rojec, M. and Trtnik, A., 2000. Strategija pospeševanja slovenskih neposrednih investicij v tujino. In Teorija in praksa, vol. 37, no. 4, pp. 623-645.

Tomšič, M., 2002. Politična stabilnost v novih demokracijah. Ljubljana: Znanstevno in publicistično središče.

Tomšič, M. and Prijon, L., 2012. Slovenia. In O Beachain, D.; Sheridan, V. and Stan, S. (eds.): Life in Post-Communist Eastern Europe After EU Membership. United Kingdom: Routledge.

Zver, M.; Živko, T. and Bobek, V., 2005. Ekonomija in kultura: Umě̌čenost Slovenije v evropski ekonomskokulturni kontekst. Koper: Fakulteta za Management. 


\section{INTERNET SOURCES}

Embassy of the Republic of Slovenia Ottawa - Veleposlaništvo republike Slovenije Otawa, 2011. Available at: http://ottawa.embassy.si/index.php?id=1554

(15.6.2012).

Izvozno okno, 2011. Bilateralni odnosi s Slovenijo. Available at:

http://www.izvoznookno.si/Iskanje/Default.aspx (15.6.2012).

The World Bank, 2012. Available at: http://data.worldbank.org (15.6.2012).

Lea Prijon, PhD. candidate and teaching assistant at School of Advanced Social Studies in Nova Gorica, Slovenia. A Young Researcher at Iskra zaščite d.o.o. Operation part financed by the European Union, European Social Fund. Operation implemented in the framework of the Operational Programme for Human Resources Development for the Period 2007 - 2013, Priority axis 1: Promoting entrepreneurship and adaptability, Main type of activity 1.1.: Experts and researchers for competitive enterprises. Her field of interests belongs to researching Slovenian economic situation and economic elite.

Lea Prijon, $\mathrm{PhD}$. School of Advanced Social Studies

Kidričeva 9

5000 Nova Gorica

Slovenia

E-mail: lea.prijon@fuds.si 